\title{
Silvicultural herbicides in Canada: registration status and research trends
}

\author{
by Robert A. Campbell ${ }^{1}$
}

\section{Abstract}

At present, there are five herbicides (2,4-D, glyphosate, hexazinone, simazine, and triclopyr) available to forest managers in Canada. It is unlikely that any new active ingredients will be registered for forestry in the foreseeable future. The only additions likely are extensions of existing labels (e.g., aerial application of Pronone ${ }^{\circledR}$ and Release ${ }^{\circledR}$ ) and registration of new formulations (e.g., Velpar ${ }^{\circledR}$ ULW). Research in the short term future will concentrate on improving efficacy, efficiency and versatility, and reducing environmental impact of currently registered products. Some of the current work is described.

Key words: silviculture, herbicide, 2,4-D, glyphosate, hexazinone, simazine, triclopyr, research trends, application technology, cost-benefit, vegetation management model, environmental impact

\section{Résumé}

Actuellement, cinq phytocides $(2,4-\mathrm{D}$, glyphosate, hexazinone, simazine, et triclopyr) demeurent à la disposition des gestionnaires forestiers au Canada. Il est peut probable que d'autres ingrédients actifs soient homologués en foresterie dans un proche avenir. Les seuls ajouts seront probablement constitués de la prolongation d'étiquettes existantes (p.e., l'utilisation en pulvérisation aérienne du (Pronone ${ }^{\circledR}$ et Release ${ }^{\circledR}$ ) et l'homologation de nouvelles formulations (p.e., $\left.\operatorname{Velpar}^{\circledR} \mathrm{ULW}\right) . \mathrm{La}$ recherche dans un avenir à court terme se concentrera sur l'amélioration de l'efficacité, de l'efficience et de la versatilité, et sur la réduction des impact environnementaux des produits actuellement homologués. Une description de quelques-uns des travaux en cours est présentée.

Mots clés: sylviculture, phytocide, 2,4-D, glyphosate, hexazinone, simazine, triclopyr, tendances en recherche, technologie d'application, coût-bénéfice, modèle de gestion de la végétation, impact environnemental

\section{Introduction}

At the 1989 CIF Annual Meeting, I discussed three topics relating to forestry herbicide use in Canada: (i) use statistics (ii) regulatory status, and (iii) technology gaps as perceived by forest managers (Campbell 1990). This paper will cover two topics: (i) an update on registration/development status of significant forestry herbicides, and (ii) an outline of herbicide research going on in Canada at present.

\section{Registration/Development Status (as of July 1991) \\ 2,4-D}

There has been no recent change in regulatory status (Campbell 1990). There was however, another major review of the hazard of 2,4-D to human health. The report of a workshop sponsored by the Harvard School of Public Health states, "In assessing all of the evidence on 2,4-D, workshop participants were not convinced that a cause-effect relationship between exposure to 2,4-D and human cancer exists" (Graham 1990).

\section{Glyphosate}

There was no change in status of either the registered forestry glyphosate product, Vision ${ }^{\circledR}$, or in the development of the glyphosate-TMS product, Touchdown ${ }^{\circledR}$ (Campbell 1990).

A new glyphosate product called E-Z-JECT ${ }^{\circledR}$ has been registered. The glyphosate is formulated as a paste in small capsules, which can be injected into single undesirable woody stems using a special lance. Although the product was registered in 1990, the lance was not commercially available until early in 1991. Some efficacy data for this system can be found in Bergerud (1988).

${ }^{1}$ Research Scientist, Forest Pest Management Institute, Forestry Canada, Sault Ste. Marie, Ontario.

\section{Hexazinone}

Contrary to expectations (Campbell 1990), an aerial registration for Velpar ${ }^{\circledR} \mathrm{L}$ was not obtained in time for the 1990 field season. The aerial use pattern was approved in December of 1990 but the certificate of registration (which is required before use) was not issued until June 1991. The approved aerial use is essentially the same as the ground broadcast use that has been registered since 1984 . Velpar ${ }^{\circledR} \mathrm{L}$ may be applied aerially for site preparation prior to planting. Black spruce, white spruce, and bare root jack pine stock can be planted immediately on medium and fine textured soils where the organic layer has not been removed following an application of $2.16 \mathrm{~kg}$ ai/ha. If rates greater than $2.16 \mathrm{~kg}$ $\mathrm{ai} / \mathrm{ha}$ are used, or if the organic layer has been removed or severely disturbed, or if container jack pine stock is to be planted, planting should be delayed until the year following treatment. Species controlled by broadcast applications include: brome grass, bluejoint, goldenrod and raspberry. Velpar ${ }^{\circledR} \mathrm{L}$ may not be used on coarse-textured soils. The new label specifies buffer zones around bodies of water (50 metres for ground application and 100 metres for aerial application).

Registration of Velpar ${ }^{\circledR}$ ULW (ground and aerial) and aerial registration of Pronone ${ }^{\circledR}$ were contingent upon an aerial $\operatorname{Velpar}^{\circledR} \mathrm{L}$ registration, so it is hoped that these registrations will be granted soon.

\section{Simazine}

There has been no change in the status of simazine (Campbell 1990).

\section{Triclopyr}

Although the registrant hoped to receive registration for forestry in 1990 (Campbell 1990), a certificate of registration for ground application of Release ${ }^{\circledR}$ herbicide (triclopyr 
ester) was not issued until July 1991. The approved use includes conifer release and site preparation. Application may be broadcast, single stem foliar, basal bark or cut stump. Target species include: alder, ash, birch, cherry, maple, oak, poplar, raspberry, salal, willow and many broadleaved herbaceous weeds. For broadcast site preparation, conifer planting should be delayed until the following year. The only conifers specifically listed for broadcast release are white spruce, black spruce and jack pine. There is no proscription against using the product to release other conifer species but the registrant would not be liable for crop damage.

The registrant hopes to get an aerial registration soon ${ }^{3}$.

\section{Sulfometuron methyl}

The manufacturer still has no intention of pursuing registration in Canada.

\section{Metsulfuron methyl, imazapyr and fluroxypyr}

Three different companies are involved but the message is the same. They are still evaluating market and development costs before deciding whether to proceed with further forestry development work in Canada.

\section{Research Trends}

Rather than review all forestry herbicide research in Canada, I will discuss briefly current research trends, the reasons for these trends, and provide some examples.

Prior to the mid 1970's, there was little forestry herbicide or vegetation management research in Canada. Then, the only herbicides available to foresters were 2,4-D, 2,4,5-T and simazine. In the mid 1970's, three new active ingredients that showed promise for forestry were identified, viz., glyphosate, hexazinone and triclopyr. These herbicides had the potential to control species that were thwarting forest renewal on the more productive sites and could not be controlled by existing herbicides. As a result, there was a major increase in forest herbicide research. There were still relatively few researchers working in this field, so most of the initial effort was directed to generating efficacy and tolerance data.

We now know that 2,4-D, glyphosate, hexazinone, simazine and triclopyr control competing vegetation and we know that crop trees have considerable tolerance. For this reason, little basic efficacy and crop tolerance research is being carried out at present. Furthermore, there will not likely be much in future. The long delays in obtaining forestry registrations, provincial restrictions and the constant controversy about forestry use of herbicides will discourage manufacturers from developing other forestry herbicides. This is clearly one reason for the lack of enthusiasm for development of metsulfuron methyl, imazapyr and fluroxypyr.

Although we have basic efficacy and tolerance data for the registered herbicides, there are several knowledge gaps:

1. We have not proven to the satisfaction of everyone concerned (foresters, regulators and the public) that herbicides do not cause significant negative environmental impact or adversely affect human health.

2. We have not demonstrated quantitative long-term crop benefit.

\footnotetext{
${ }^{3}$ It seems to be futile to try to estimate when a registration will be granted. In 1983, I stated that triclopyr was not currently registered but might be by 1984 (Campbell 1984).
}

3. We know that we are not using herbicides as effectively as we could be.

Most current research is designed to address one or more of these areas of concern.

\section{Environmental Impact/Human Health}

This knowledge gap is the most important because concerns about environmental impact and human health are the most common reasons for forest herbicide use to be restricted or prohibited. Unfortunately, good science is often not enough to allay these concerns. In all seriousness, I think we need to get some social scientists working on the problem of gaining public acceptance for a tool which we believe is essential and does not pose a significant health or environmental hazard.

\section{Environmental Fate}

The first question to be asked when investigating environmental impact is, "What happens to the herbicide after it is sprayed?', (How much gets into the various environmental components? Does it move within the soil profile? How fast does it dissipate? What are the degradation products?). A lot of environmental fate work has been done on Canadian forest sites. The most active groups have been: Forest Pest Management Institute, Northern Forestry Centre, Québec Ministrère de l'Énergie et des Ressources, University of Guelph and University of Toronto (Table 1). In general, environmental fate studies, in combination with toxicity studies, have indicated that direct toxicity to fish and wildlife is unlikely under normal use conditions.

\section{Habitat Effects}

Because herbicides affect vegetation, they can affect fish and wildlife habitat. Thus, most of the research on the impact of herbicides on fish and wildlife is directed toward effects on habitat. Some examples of recent Canadian research are listed in Table 2 .

\section{Buffer Zones}

In most jurisdictions, local regulatory agencies require that buffer zones be established around areas of concern (water bodies, human habitation, apiaries, etc.) during aerial spraying programs. The width of the buffer required for protection of the same resource varies dramatically from one jurisdiction to the next (Trial 1987). This is partly because there is little scientific basis for defining buffer width (Trial 1987), and what there is has frequently been weak. The first question that needs answering is, "How much herbicide drifts, and what are the effects of meteorological conditions and the delivery system?"' This is not a simple question a lot of variables must be considered and each variable has a wide range of intensities or levels. Consequently, the problem is being approached from two directions. First, drift studies are used to measure herbicide that is airborne and/or deposited downwind using different delivery systems and under different atmospheric conditions. This work is being done at the Forest Pest Management Institute (Payne et al. 1990) and at the Research and Productivity Council in Fredericton, NB (Riley et al. 1991). Data from drift studies, together with data on droplet spectra produced by different atomizers (Picot et al. 1989), are used in models designed to extrapolate results to other scenarios (different wind speed, 
Table 1. Selected environmental fate studies of herbicides on forest sites in Canada

\begin{tabular}{|c|c|c|c|c|c|}
\hline & 2,4-D & Glyphosate & Hexazinone & Triclopyr & Metsulfuron \\
\hline Water & Solomon et al. 1988 & $\begin{array}{l}\text { Feng et al. } 1990 \\
\text { Legris and Couture } 1990\end{array}$ & $\begin{array}{l}\text { Feng and Feng } 1988 \\
\text { Legris and Couture } 1987 \\
\text { Solomon et al. } 1988\end{array}$ & $\begin{array}{l}\text { Solomon et al. } 1988 \\
\text { Thompson et al. } 1991\end{array}$ & $\begin{array}{l}\text { FPMI }^{1} \text { in } \\
\text { progress }\end{array}$ \\
\hline Soil & Thompson et al. 1984 & $\begin{array}{l}\text { Feng and Thompson } 1990 \\
\text { Roy et al. 1989a } \\
\text { Legris and Couture } 1990\end{array}$ & $\begin{array}{l}\text { Feng } 1987 \\
\text { Feng and Feng } 1988 \\
\text { Legris and Couture } 1987 \\
\text { Roy et al. } 1989\end{array}$ & Stephenson et al. 1990 & $\begin{array}{l}\text { FPMI }^{1} \text { in } \\
\text { progress }\end{array}$ \\
\hline Sediment & Solomon et al. 1988 & $\begin{array}{l}\text { Feng et al. } 1990 \\
\text { Legris and Couture } 1990\end{array}$ & $\begin{array}{l}\text { Legris and Couture } 1987 \\
\text { Solomon et al. } 1988\end{array}$ & $\begin{array}{l}\text { Solomon et al. } 1988 \\
\text { Thompson et al. } 1991\end{array}$ & $\begin{array}{l}\text { FPMI }^{1} \text { in } \\
\text { progress }\end{array}$ \\
\hline Litter & & Feng and Thompson 1990 & & & \\
\hline Foliage & & $\begin{array}{l}\text { Feng and Thompson } 1990 \\
\text { Legris and Couture } 1990\end{array}$ & & & \\
\hline Berries & Frank et al. 1983 & $\begin{array}{l}\text { Legris and Couture } 1990 \\
\text { Roy et al. } 1989 \text { c }\end{array}$ & & & \\
\hline
\end{tabular}

${ }^{1}$ Forestry Canada, Forest Pest Management Institute.

Table 2. Selected habitat studies of herbicides on forest sites in Canada

\begin{tabular}{|c|c|c|c|c|}
\hline & Glyphosate & Hexazinone & Triclopyr & Metsulfuron \\
\hline Aquatic invertebrates & $\begin{array}{l}\text { Kreutzweiser et } \\
\text { al. } 1989 \\
\text { Scrivener and } \\
\text { Carruthers } 1989\end{array}$ & $\begin{array}{l}\text { FPMI }^{1} \text { in } \\
\text { progress }\end{array}$ & $\begin{array}{l}\text { FPMI }{ }^{1} \text { in } \\
\text { progress }\end{array}$ & \\
\hline Algae & $\begin{array}{l}\text { Holtby and } \\
\text { Baillie 1989a }\end{array}$ & $\begin{array}{l}\text { FPMI }^{1} \text { in } \\
\text { progress }\end{array}$ & & $\begin{array}{l}\text { FPMI }^{1} \text { in } \\
\text { progress }\end{array}$ \\
\hline Zooplankton & & $\begin{array}{l}\text { FPMI }^{1} \text { in } \\
\text { progress }\end{array}$ & & $\begin{array}{c}\mathrm{FPMI}^{1} \text { in } \\
\text { progress }\end{array}$ \\
\hline Soil fauna and microflora & $\begin{array}{l}\text { Preston and } \\
\text { Trofymow } 1989\end{array}$ & & & \\
\hline Salmon habitat & $\begin{array}{l}\text { Holtby and } \\
\text { Baillie } 1989 \text { b }\end{array}$ & & & \\
\hline Moose habitat & $\begin{array}{l}\text { Connor and } \\
\text { McMillan } 1990\end{array}$ & & & \\
\hline Small mammal habitat & & Brace et al. 1988 & & \\
\hline
\end{tabular}

${ }^{1}$ Forestry Canada, Forest Pest Management Institute.

temperature, relative humidity, atmospheric stability, spray height, delivery system, formulation, etc). Further drift studies are then done to improve model fit. There is no perfect model, but two major ones are FSCBG, developed by the USDA Forest Service and PKBW, which was developed at the University of New Brunswick ${ }^{4}$. Because neither model is suitable for in-the-field decision making, Monsanto is attempting to have a new model developed which could be used to make go/no-go decisions in the field.

Knowing how much drift is going to occur in a given situation is only the first step in setting a rational buffer zone. The next question is, "How much deposit and/or impact is acceptable in the resource to be protected?' Specifying no deposit is unrealistic because the downwind distance to a nodeposit level increases as the sensitivity of detection increases. Since plants are usually the most sensitive organisms to herbicides, one approach is to utilize deposit levels which cause no effect on plants. This has been done

\footnotetext{
${ }^{4}$ Mickle (1987) compared the performance of these two models for insecticide drift.
}

for hexazinone (Campbell et al. 1986) and glyphosate (Payne, pers. commun.). It is likely that one of the requirements for registration in the future will be no-effect levels for a wide variety of non-target plants.

\section{Worker Exposure}

Requirements for human safety associated with pesticide use have led to more research on human exposure. The study of Frank et al. (1985) on 2,4-D exposure was completed because workers wanted proof that they would not be harmed by working with herbicides. Exposure studies have also been done for glyphosate (Centre de Toxicologie du Québec, 1988) and hexazinone (Bertrand and Dugal 1988). Worker exposure studies are now required for new registrations. In 1990, DowElanco carried out such a study to support their submission for an aerial registration of Release ${ }^{\circledR}$ herbicide (triclopyr). Such worker exposure studies are feasible for major forestry herbicides, but when it comes to forest nursery herbicides there is a problem. No chemical company is going to spend $\$ 100,000$ or more on a worker exposure study to support a herbicide that will be used on less than 50 ha per 
year across Canada $^{5}$. A partial solution to this problem would be the development of exposure models which would reduce the need for expensive monitoring studies in the field.

\section{Benefit Data}

Three different types of benefit data are needed: (i) the need for vegetation management (ii) herbicide A vs herbicide $\mathrm{B}$ and (iii) herbicide vs other options.

First, since almost any forest management activity is controversial these days, we need to prove that vegetation management itself is necessary to ensure successful forest renewal. Most experienced forest managers believe that it is, but we have very little hard long-term data to support the belief $^{6}$. In 1985, a cost-benefit analysis was done on 2,4-D/2,4,5-T used for conifer release (Roberts et al. 1985). Chemical release was compared with manual release and no release. The authors highlighted the following difficulties in doing such an analysis: (i) an unsubstantial database (ii) the long-term nature of responses and (iii) the heterogeneity of forest sites and forest vegetation. They stated, "Although volume increases of $265 \%$ resulting from chemical treatment were reported after 30 years, without curves demonstrating the future development of the stand until harvest, the number of trees per cubic metre, and time to harvest, the results can not be extrapolated with any degree of confidence to determine the actual benefits from the treatments."

It is essential that trials be established to generate longterm cost-benefit data on a wide variety of sites. Maintaining these trial sites unaltered during subsequent harvesting, renewal and tending operations in the vicinity will require long-term effort and commitment of the forest managers.

The second type of benefit data compares one herbicide with another. One of the difficulties (in addition to those mentioned above) is the fact that very few side by side comparisons have been made with different herbicides and formulations. The Forest Pest Management Institute has a couple of comparative studies underway. One compares liquid vs granular formulations of hexazinone (Reynolds et al. 1988). The other compares triclopyr with three different formulations of glyphosate (D. Pitt, pers. comm.).

\footnotetext{
${ }^{5}$ This was not a problem until 1988. Prior to that time, most forest nursery managers considered that if a herbicide was registered for agricultural use it could be used in forest tree nurseries as long as it was applied under the conditions specified on the label (soil type, rates, etc.), even if forest tree species were not listed as crops on the label. Now the interpretation is that the species and timing must be on the label. Thus there is a major effort under the auspices of the Canadian Forest Nursery Weed Management Association to generate the hard efficacy and crop tolerance data required for registration. If worker exposure studies are required, it is not clear how they would be funded. The USDA Forest Service funded a major study (Lavy et al. 1990) but, unfortunately, there is not much overlap between the herbicides they studied and those available and/or used in Canada.

${ }^{6}$ In 1987, the Ontario Ministry of Natural Resources attempted to generate long-term benefit data. At that time they had been using 2,4-D for forest vegetation management for over 30 years. District records across the province were searched for situations where one portion of a site was treated with herbicide and the other wasn't. Although a large number of untreated blocks were found, the oldest usable one was 12 years post spray. Untreated blocks were not left intentionally for comparison purposes. In all cases, there was a legitimate reason why the untreated block had not been treated (e.g., it hadn't been planted, there was less competition on the untreated block than on the treated block, the untreated site was different from the treated site resulting in crop tree survival differences for reasons other than competition, etc.).
}

Studies comparing one herbicide to another will become essential if, as is possible in the future, it will not be possible to register a herbicide unless the proponent can prove that the new herbicide can provide benefit for the crop beyond that possible with currently registered herbicides. The Forestry Pesticides Caucus ${ }^{7}$ conducted a cost-benefit case study on triclopyr to assist Agriculture Canada to decide what type of benefit data should be required to support registration submissions in the future (Deloitte \& Touche 1991).

The third type of benefit data required compares herbicides with other methods of vegetation management. Right now, we have the same difficulty that we have in demonstrating the benefit of vegetation management. Herbicides and the other options have been used for many years but seldom side by side. There is currently a major effort in British Columbia to fill this gap ( $R$. Whitehead, pers. commun.). The Alberta Forest Service and Forestry Canada are comparing selected manual, mechanical and chemical methods of site preparation and release (Brace et al. 1988). The most extensive program in North America to compare all silvicultural alternatives for vegetation management (chemical, mechanical, mulches, fire, grazing) is that of the USDA Forest Service Pacific Southwest Forest and Range Experiment Station at Redding, California. The California studies are designed to determine what works under what conditions at what cost (e.g. McDonald and Fiddler 1989).

If we want to change public perception that alternatives to chemical methods of vegetation management are universally applicable, we will have to do a lot more comparative studies. Furthermore, because economic models and statistics in scientific publications are not very convincing to the layman, the studies will have to be established in accessible locations so that politicians, regulators and the public can see the comparisons for themselves. From a scientific point of view, if cost-benefit analyses are to be valid for the wide range of sites and vegetation types which exist in Canada, studies will have to incorporate a large number of variants.

\section{Optimizing Herbicide Use}

Many of us would like to be able to concentrate our efforts on optimizing herbicide use because research in this area can result in more effective forest renewal.

\section{Ground Application Technology}

In Canada, the bulk of forestry herbicides are applied aerially (Campbell 1990). The major reason for this is that ground application is limited by the following factors (Galloway 1988):

- variable speed (resulting in over or under application)

- crooked application lines (resulting in skips and overlaps)

- low productivity (especially important because of the narrow window for application)

- site access (e.g. accessible only in winter)

- site operability (e.g. very steep)

- high cost.

\footnotetext{
$\overline{7 \text { “ The Forestry Pesticides Caucus is a national body of pest management }}$ experts representing forest industry trade associations, provincial and federal governments, academia, the forestry profession, woodlot owners, and vegetation managers." It was formed to coordinate the participation of the forest sector in the Pesticide Registration Review and to develop an economic benefit analysis from a forest protection perspective. (Can. Pulp Paper Assoc., For. Protect. Commun., Aug 1989).
} 
In spite of these limitations, and because of the potential for restrictions on aerial application, there has been an increased interest in ground application equipment.

The Forest Engineering Research Institute of Canada (FERIC) is currently completing a report on ground application equipment (Desrochers and Dunnigan 1991). This is not an evaluation but rather a descriptive listing of what is commercially available and has been constructed - similar to the Silvicultural Equipment Reference Catalog for Southern Ontario (Smith). The Northwestern Ontario Forest Technology Development Unit has a study to compare efficacy, cost and logistics of a number of different ground application methods for conifer release (R. Wagner, pers. commun.).

Most research on ground applicators is aimed at minimizing one or more of the above limitations. Application costs can be reduced by mounting the application equipment on mechanical site preparation equipment. This was the rationale behind the Bracke Herbicider, which was developed by $\mathrm{kbm}$. That company is currently working on a Velpar $^{\circledR}$ ULW applicator that can be mounted on the prime mover during mechanical site preparation.

The non-uniform speed problem has been approached by tying applicator output to ground speed. This is a feature of the Bracke Herbicider and the Omni Spray granular applicator. This solution is not straightforward. The application equipment must be capable of changing output very rapidly and must operate effectively over a wide range of outputs to reflect sudden and major changes in speed during mechanical site preparation. The latter criteria are more difficult to meet for liquid applicators using hydraulic nozzles than for granular applicators, because such nozzles normally function optimally over about a two-fold pressure range. Below this range, the pattern (fan or cone) tends to collapse. Above this range, the spray tends to be too fine, resulting in excessive drift and non-uniform deposit. The nozzle output range limitation was overcome by use of a system which injects concentrated herbicide product into the water carrier just prior to the nozzle at a rate tied to ground speed (Edwards and Miller 1991). This allows the total spray volume per minute to be kept constant although it results in a variable total spray volume per hectare.

Mistblowers are being examined by Ontario Ministry of Natural Resources (Howard and Osborn 1989). This is not a new technique - it was used extensively in the southeastern U.S. during the 1960's and $70^{\prime} \mathrm{s}^{8}$. There are several potential advantages of mistblowers over conventional ground sprayers using hydraulic cluster nozzles.

- Wider swath (up to $30 \mathrm{~m}$ )

- Lower total spray volume/ha means that a smaller tank can be used; this allows the whole unit to be mounted on a skidder making it more maneuverable than a towed unit.

- Better coverage when there are tall obstacles on the site; the air blast tends to curve around obstacles whereas spray from a hydraulic nozzle is simply blocked.

\footnotetext{
${ }^{8}$ The fact that it is little utilized now is a reflection of the move to clearcut management systems where aerial application is more appropriate (D. Gjerstad, pers. commun.). It is interesting, however, that the cover photo on a 1965 herbicide guide for foresters in the southeastern U.S. is of a mistblower operating in an apparent clearcut (Romancier 1965).
}

Preliminary results indicate that mistblowers are not appropriate for cutovers as there is too much off-target movement, and deposit is not sufficiently uniform. They do, however, look very promising for shelterwood situations. Forest managers wanting to use a mistblower will have to modify their harvesting practices to minimize the difficulty in travelling in straight lines through a shelterwood stand (i.e., harvesting will have to be done such that application paths are created). Although deposit seems to be good, efficacy and crop tolerance need to be checked. Optimum active ingredient rates and application volumes also need to be examined.

\section{Aerial Application Technology}

When using aerial application, forest managers would like to: (i) increase productivity (ii) decrease cost (iii) increase efficacy and, (iv) decrease off-target movement. There are a number of approaches to these goals. Reducing carrier volume will increase productivity and reduce costs, but it is not clear whether efficacy will be maintained. There is evidence that efficacy may be enhanced by using smaller droplets (Prasad and Cadogan 1987). Use of narrower spectrum atomizers could reduce off-target movement by reducing the drift-prone fraction of the spray cloud.

The Forest Pest Management Institute, in conjunction with the New Brunswick Department of Natural Resources \& Energy, has compared glyphosate application using Micronair rotary atomizers vs conventional hydraulic nozzles (i.e., will smaller drops and a narrower spectrum increase efficacy thus allowing active ingredient rates to be reduced?) (D. Pitt, pers. commun.). The Forest Pest Management Institute is also examining the relationship between active ingredient rate, spray volume and drop size for glyphosate on raspberry in simulated aerial applications. The drift and spray model research discussed earlier is relevant to the desire to reduce off-target movement.

\section{Competition Indices}

One of the oldest and most frequently asked questions in forest vegetation management is, "How can I tell if this plantation needs to be released?" The determination has normally been subjective. Some experienced forest managers probably have a good intuitive feel for the matter. Unfortunately, in practice, much of the operational determination is made by inexperienced personnel. To answer the question, two things are needed: (i) a quantitative measure of the competing vegetation and, (ii) a relationship between the quantity of competing vegetation and crop tree performance (often referred to as a competition index). A considerable amount of research is being done in this area at various establishments across Canada (e.g., Maritimes Forestry Centre (Salonius et al. 1991), Forest Pest Management Institute, Petawawa National Forestry Institute, Northwestern Ontario Forest Technology Development Unit (Towill and Archibald 1991), and University of British Columbia). This will continue to be an active area of research for some time as there are no simple solutions. Not only will competition indices probably vary depending on whether one is considering survival, height growth or diameter growth but they will also probably vary with site quality, competing species, seasonal variation, and stage of stand development (Wagner et al. 1989). There is usually not a good correlation between simple measures of vegetation density and 
crop tree performance ${ }^{9}$, so research is needed to find measures of vegetation that better represent competitive pressure (Wagner et al. 1989).

One way of approaching the poor correlation problem is by determining the nature of competition (Does competing vegetation compete by limiting crop tree access to light, moisture or nutrients? Is allelopathy involved?). Work of this type is going on at the Newfoundland Forestry Centre, the Forest Pest Management Institute and the University of British Columbia. As an example, the strong competitive pressure exerted by Kalmia on black spruce does not seem to be related to light or moisture. If it is allelopathic, use of a herbicide to kill the Kalmia may not help the crop (B. Titus, pers. commun.).

\section{Vegetation Management Models}

In addition to the numerous factors that can affect competition indices, another problem with them is that they are static. A competition index can indicate whether the current level of competition is having a negative effect on the crop trees but it can not forecast future effects (Wagner et al. 1989). A logical extension of the idea of competition indices is the development of models that would predict competition and thus facilitate proactive rather than reactive vegetation management. In fact, it has been suggested that competition indices may have a fairly limited utility. Caza and Kimmins (1990) state, "It is suggested that an approach employing dynamic simulation models responsive to changing conditions over time and space may yield greater potential for the development of management tools for the assessment and prediction of vegetation problems.' Descriptions of a number of the growth models currently under development (ZELIG, CLUMP, FORCYTE, FORECAST, df et al.) can be found in Hamilton (1990). In addition to growth models, models are also being developed to assist in selection of the best vegetation management alternative once the need has been identified. I don't believe that any of the latter type of model are being developed in Canada, but there is one for the Pacific Northwest called VegPro (Wagner 1990) and one for southern pines called ChESS (S.M. Zedaker, pers. commun.).

\section{Rate Refinement}

This needs to be done for local conditions - optimizing rates, timing, etc. work has been done in Nova Scotia checking lower than recommended rates (Chase et al. 1990) and seasonal variation in conifer tolerance (N.S. Dept. Lands and Forests 1989). A lot of this work is done by operational people. Although it is a potential source of much useful information, there are two reasons why it represents only potential. First, many trials are trying one treatment or rate one year and another the next year (i.e., there are no side by side comparisons). Second, although many of these trials result in important information, it does not get reported. The Expert Committee on Weeds Annual Research Report provides a good vehicle for communicating this type of trial and should be used more frequently. Reports are limited to one page so they are not onerous to prepare.

\footnotetext{
${ }^{9}$ The lack of appropriate assessment methods is one of the reasons why long-term benefit data is so variable. Such data are seldom tied to a quantitative measure of competitive pressure at the time of treatment.
}

\section{Acknowledgments}

I would like to thank Peter de Groot for providing me with the opportunity to make this presentation. I would also like to thank the numerous people who helped me prepare this paper by taking time to discuss their research programs.

\section{References}

Bergerud, W.A. 1988. Dose-response models for stand thinning with the "Ezject" herbicide injection system. B.C. Min. For., Res. Br., Victoria, BC. Res. Note. No. 102. 28 p.

Bertrand, N. and J. Dugal. 1988. Concentrations d'hexazinone dans l'air et exposition des travailleurs lors d'une application terrestre, en 1988. Gouvernement du Québec, Ministère de l'Énergie et des Ressources, Direction de la conservation. Publ. 3326.

Brace, L.G., S. Sidhu, and D. Boylen. 1988. Vegetation management research project, Grande Prairie, AB: progress report. For. Can., North. For. Cent., Edmonton, AB.

Campbell, R.A. 1984. The value of herbicides in forest management. Can. For. Indust. 104 (31): 41-44.

Campbell, R.A. 1990. Herbicide use for forest management in Canada: where we are and where we are going. For. Chron. 66 (4): $355-360$.

Campbell, R.A., C.A. Hope, and S.A. Nicholson. 1986. An aerial velpar drift study. Pest Control Sect., Min. Nat. Res., Maple, ON.

Caza, C.L. and J.P. Kimmins. 1990. Problems with the development and application of competition indices in complex, multispecies communities. In Vegetation Management: an Integrated Approach. Proceedings of the Fourth Annual Vegetation Management Workshop, 14-16 November 1989, Vancouver, BC. Compiled by E. Hamilton. Res. Br., B.C. Min. For., Victoria, BC. FRDA Rep. 109. pp. 30-32.

Centre de Toxicologie du Québec. 1988. Étude de l'exposition professionelle des travailleurs forestiers exposés au glyphosate. Le Centre de l'Université Laval, Sainte-Foy, PQ. 27 p.

Chase, B., T. McGrath, R. McNally, and P. Romkey. 1990. Controlling raspberry and red maple in Nova Scotia with lower than recommended rates of glyphosate. Proc. Northeast. Weed Sci. Soc. 44: 61-66.

Connor, J.F. and L.M. McMillan. 1990. Winter utilization by moose of glyphosate-treated cutovers. Ont. Min. Nat. Res., NW Ont. For. Tech. Dev. Unit, Thunder Bay, ON. Tech. Rep. \#56.

Deloitte \& Touche Management Consultants. 1991. Economic benefit assessment of triclopyr in forest management. Prepared for the Forest Pest Management Caucus. Deloitte \& Touche Management Consultants, Guelph, ON. 111 p.

Desrochers, L. and J. Dunnigan. 1991. Mobile ground sprayers for ground application of herbicides. Forest Engineering Research Institute of Canada, Pointe Claire, PQ. 42 p. (draft). (Ce rapport sera disponsible en français aussi).

Edwards, M.B. and J.H. Miller. 1991. A comparison of site preparation herbicides $-5 \mathrm{yr}$ pine growth. Presentation at the 44th Ann. Meet. South. Weed Sci. Soc., 14-16 January 1991, San Antonio, TX.

Feng, J.C. 1987. Persistence, mobility and degradation of hexazinone in forest silt loam soils. J. Environ. Sci. Health B22: 221-233.

Feng, J. and C. Feng. 1988. Determination of hexazinone residues and their fate in a New Brunswick forest. Forest Pest Manage. Inst., Can. For. Serv., Sault Ste. Marie, ON. Inf. Rep. FPM-X-81.

Feng, J.C., D.G. Thompson, and P.E. Reynolds. 1990. Fate of glyphosate in a Canadian forest watershed. 1. Aquatic residues and off-target deposit assessment. J. Agric. Food Chem. 38: 1110-1118. 
Frank, R., R.A. Campbell, and G.J. Sirons. 1985. Forestry workers involved in aerial application of 2,4-D: Exposure and urinary excretion. Arch. Environ. Contam. Toxicol. 14: 427-435.

Frank, R., G.J. Sirons, R.A. Campbell, and D. Mewett. 1983. Residues of 2,4-D, dichlorprop and picloram in wild berries from treated rights-of-way and conifer release sites in Ontario, 1979-1981. Can. J. Plant Sci. 63: 195-209.

Galloway, R. 1988. Report on cleaning by aerial and ground herbicide application for conifer release. In Statement of evidence panel XII, maintenance: tending. Class Environmental Assessment for Timber Management on Crown Lands in Ontario. Ont. Min. Nat. Res., Toronto. pp. 147-193.

Graham, J.D., ed. 1990. The weight of the evidence on the human carcinogenicity of 2,4-D. Program on Risk Analysis and Environmental Health, Harvard School of Public Health, Boston, MA.

Hamilton, E. comp. 1990. Vegetation Management: an Integrated Approach. Proceedings of the Fourth Annual Vegetation Management Workshop, 14-16 November 1989, Vancouver, BC. Res. Br., B.C. Min. For., Victoria, BC. FRDA Rep. 109.

Holtby, L.B. and S.J. Baillie. 1989a. Effects of the herbicide Roundup (glyphosate) on periphyton in Carnation Creek, British Columbia. In Proceedings of the Carnation Creek Herbicide Workshop, 7-10 December 1987, Nanaimo, BC. Edited by P.E. Reynolds. Min. For., Victoria, BC. FRDA Rep. 063. pp. 224-231.

Holtby, L.B. and S.J. Baillie. 1989b. Effects of the herbicide Roundup (glyphosate) on coho salmon fingerlings in an oversprayed tributary of Carnation Creek, British Columbia. In Proceedings of the Carnation Creek Herbicide Workshop, 7-10 December 1987, Nanaimo, BC. Edited by P.E. Reynolds. Min. For., Victoria, BC. FRDA Rep. 063. pp. 273-285.

Howard, C.A. and W.P.L. Osborn. 1989. Trial of the air blast sprayer as a herbicide applicator for site preparation and conifer release. For. Health Protect. Sect., Min. Nat. Res., Sault Ste. Marie, ON.

Kreutzweiser, D.P., P.D. Kingsbury, and J. Feng. 1989. Drift response of stream invertebrates to aerial application of glyphosate. Bull. Environm. Contam. Toxicol. 42: 331-338.

Lavy, T.L., J.D. Mattice, J.H. Massey, and B.W. Skulman. 1990. Pesticide exposure assessment of nursery workers. USDA For. Serv., Washington, DC.

Legris, J. and G. Couture. 1987. Étude préliminaire des résidus d'hexazinone dans l'environment, suite à des travaux de préparation de terrain en milieu forestier, 1986. Gouvernement du Québec, ministère de l'Énergie et des Ressources, Service des études environnementales. Publ. No. 3317.

Legris, J. and G. Couture. 1990. Résidus de glyphosate dans un écosystème forestier suite à des pulvérisations aériennes au Québec en 1987. Gouvernement du Québec, ministère de l'Énergie et des Ressources, Services des études environnementales. Publ. No. ER90-3085.

McDonald, P.M. and G.O. Fiddler. 1989. Competing vegetation in ponderosa pine plantations: ecology and control. USDA For. Serv., Pacific SW For. Range Expt. Stn., Berkeley, CA. Gen. Tech. rep. PSW-113.

Mickle, R.E. 1987. A review of models for ULV spraying scenarios. In Proceedings Symposium on the Aerial Applications of Pesticides in Forestry, 20-22 October 1987, Ottawa. Edited by G.W. Green. Assoc. Comm. Agr. For. Aviat., Nat. Res. Coun. Can., Ottawa, ON. NRC No. 29197. pp. 179-188.

Nova Scotia Dept. Lands and Forests, Forest Research Section. 1989. Conifer susceptibility to glyphosate in Nova Scotia. Truro, NS. For. Res. Rep. No. 10.
Payne, N.J., J.C. Feng, and P.E. Reynolds. 1990. Off-target deposits and buffer zones required around water for aerial glyphosate applications. Pestic. Sci. 30: 183-198.

Picot, J.J.C., M.W. van Vliet, and N.J. Payne. 1989. Droplet size characteristics for insecticide and herbicide spray atomizers. Can. J. Chem. Eng. 67: 752-761.

Prasad, R. and B.L. Cadogan. 1987. Influence of small droplets on herbicide toxicity. In Proceedings Symposium on the Aerial Application of Pesticides in Forestry, 20-22 October 1987, Ottawa. Edited by G.W. Green. Assoc. Comm. AGr. For. Aviat., Nat. Res. Coun. Can., Ottawa, ON. NRC No. 29197. pp. 309-313.

Preston, C.M. and J.A. Trofymow. 1989. Effects of glyphosate (Roundup) on biological activity of two forest soils. In Proceedings of the Carnation Creek Herbicide Workshop, 7-10 December 1987, Nanaimo, BC. Edited by P.E. Reynolds. Min. For., Victoria, BC. FRDA Rep. 063. pp. 122-140.

Reynolds, P.E., D.G. Pitt, and M.J. Roden. 1988. Weed efficacy and crop tolerance after site preparation with liquid and granular hexazinone formulations. Proc. Northeast. Weed Sci. Soc. 42 (Suppl.): 74-78.

Riley, C.M., C.J. Wiesner, and W.A. Sexsmith. 1991. Estimating off-target spray deposition on the ground following the aerial application of glyphosate for conifer release in New Brunswick. J. Environ. Sci. Health 826: 185-208.

Roberts, J.R., K.M. Lloyd, M. Stemeroff, G.R. Stephenson, R.F. Sutton, C.R. Ellis, L.V. Edgington, and B. Payandeh. 1985. Evaluation of the biological and economic benefits of pesticide use. Monograph V. In Strengths and limitations of benefit-cost analyses applied to the assessment of industrial organic chemicals including pesticides. Assoc. Comm. Scient. Criteria Environm. Qual., Nat. Res. Coun. Can., Ottawa, ON. NRCC No. 23988.

Romancier, R.M. 1965. 2,4-D, 2,4,5-T, and related chemicals for woody plant control in the southeastern United States. Georgia For. Res. Coun., Macon, GA. Rep. Num. 16.

Roy, D.N., S.K. Konar, S. Banerjee, D.A. Charles, D.G. Thompson, and R. Prasad. 1989a. Persistence, movement, and degradation of glyphosate in selected Canadian boreal forest soils. J. Agric. Food Chem. 37: 437-440.

Roy, D.N., S.K. Konar, D.A. Charles, J.C. Feng, R. Prasad, and R.A. Campbell. 1989b. Determination of persistence, movement, and degradation of hexazinone in selected Canadian boreal forest soils. J. Agric. Food Chem. 37: 443-447.

Roy, D.N., S.K. Konar, S. Banerjee, D.A. Charles, D.G. Thompson, and R. Prasad. 1989c. Uptake and persistence of the herbicide glyphosate (Vision) in fruit of wild blueberry and red raspberry. Can. J. For. Res. 19: 842-847.

Salonius, P.O., K.P. Beaton, and T.S. Murray. 1991. How to estimate future competition stress to better spend herbicide dollars. For. Can. - Maritimes Reg., Fredericton, NB. Tech. Note No. 251. 4 p.

Scrivener, J.C. and S. Carruthers. 1989. Changes in invertebrate populations of the main stream and back channels of Carnation Creek, British Columbia following spraying with the herbicide Roundup (glyphosate). In Proceedings of the Carnation Creek Herbicide Workshop, 7-10 December 1987, Nanaimo, BC. Edited by P.E. Reynolds. Min. For., Victoria, BC. FRDA Rep. 063. pp.263-272.

Solomon, K.R., C.S. Bowhey, K. Liber, and G.R. Stephenson. 1988. Persistence of hexazinone (VELPAR), triclopyr (GARLON) and 2,4-D in a northern Ontario aquatic environment. J. Agric. Food Chem. 36: 1314-1318.

Smith, C.R. Silvicultural equipment reference catalogue for northern Ontario. For. Resour. Br., Ont. Min. Nat. Res., Toronto, ON.

Stephenson, G.R., K.R. Solomon, C.S. Bowhey, and K. Liber. 1990. Persistence, leachability, and lateral movement of 
triclopyr (Garlon) in selected Canadian forestry soils. J. Agric. Food Chem. 38: 584-588.

Thompson, D.G., G.R. Stephenson, K.R. Solomon, and A.V. Skepasts. 1984. Persistence of (2,4-Dichlorophenoxy) acetic acid and 2-(2,4-Dichlorophenoxy)propionic acid in agricultural and forest soils of northern and southern Ontario. J. Agric. Food Chem. 32: 578-581.

Thompson, D. G., B. Staznik, D.D. Fontaine, T. Mackay, G.R. Oliver, and J. Troth. 1991. Fate of triclopyr ester (Release ${ }^{\circledR}$ ) in a boreal forest stream. Environ. Toxicol. Chem. 10: 619-632.

Towill, W.D. and D.A. Archibald, 1991. A competition index methodology for northwestern Ontario. Ont. Min. Nat. Res., NW Ont. For. Tech. Dev. Unit., Thunder Bay, ON. Tech. Note TN-10. 12 p.

Trial, J., ed. 1987. Buffer zones: their application to forest insect control operations. Proceedings of The Buffer Zone
Workshop Sponsored By The Eastern Spruce Budworm Council's Environmental Committee, 16-17 April 1986, Quebec City, PQ. For Pest Manage. Inst., Can. For. Serv., Sault Ste. Marie, ON.

Wagner, R.G. 1990. VegPro: a forest vegetation management prescription optimization and information system. In Vegetation Management: an Integrated Approach. Proceedings of the Fourth Annual Vegetation Management Workshop, 14-16 November 1989, Vancouver, BC. Compiled by E. Hamilton. Res. Br., B.C. Min. For., Victoria, BC. FRDA Rep. 109. p. 118.

Wagner, R.G., T.D. Petersen, D.W. Ross, and S.R. Radosevich. 1989. Competition thresholds for the survival and growth of ponderosa pine seedlings associated with woody and herbaceous vegetation. New For. 3: 151-170.

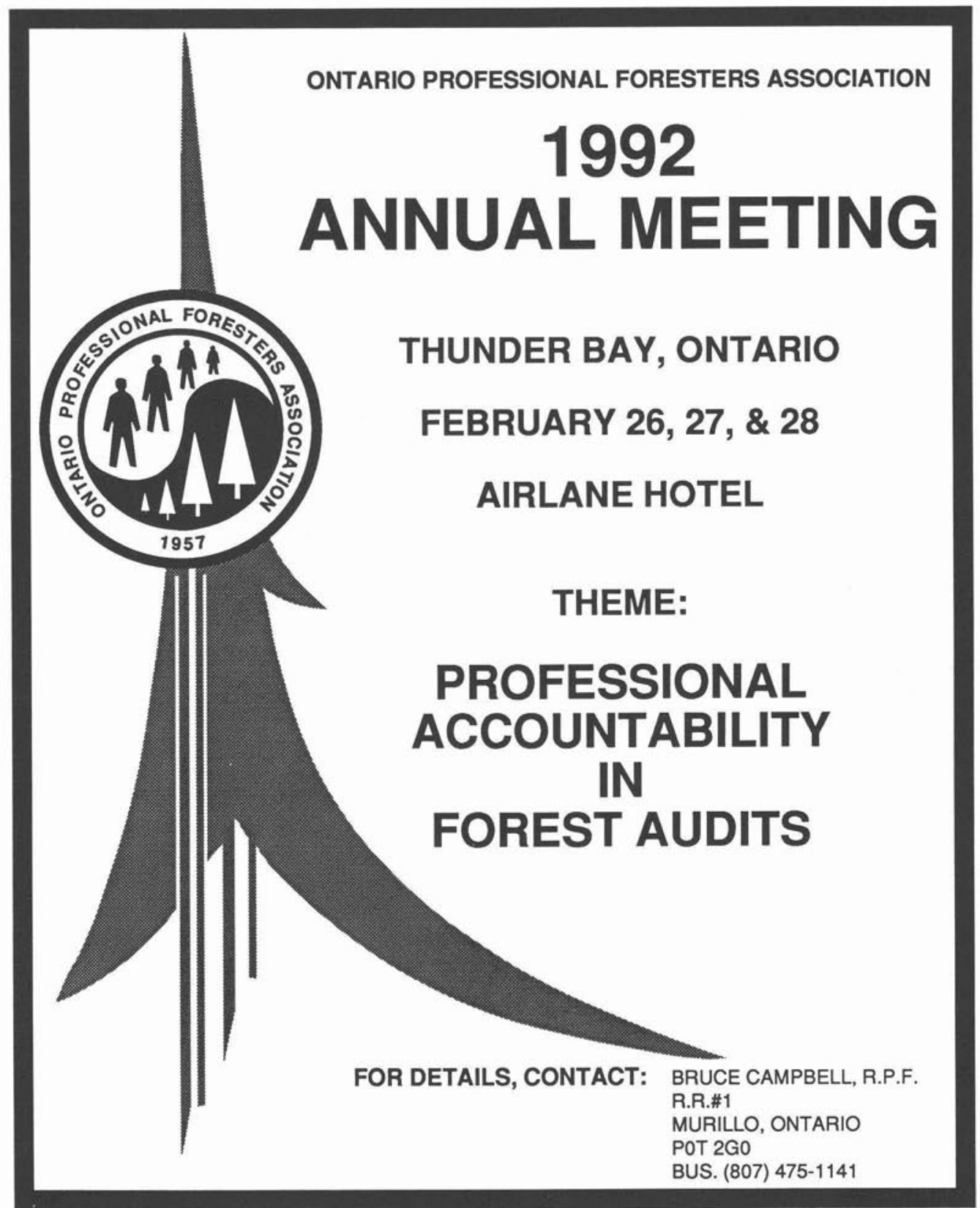

